\title{
Studi Ecological Fiscal Transfer sebagai Potensi Pendanaan Lingkungan di Daerah
}

\author{
Joko Tri Haryanto •
}

\begin{abstract}
Along with the issue of the increasing prosperity in many parts of the world, including Indonesia, the global development agenda has been shifted from proverty issues to sustainable development goals (Sustainable Development Goal's or SDG's) issues. Consecutively, to support this target achievement, the role of the budget becomes very significant, including the Transfer to the Region mechanism. Based on the analysis, the mechanism of the General Allocation Fund (DAU) has the potential to become a source of funding for environmental and ecological forestry. Ecological fiscal transfer mechanism can be manifested through the addition of DAU allocation for the benefit of environmental conservation and forestry. It also can be embodied through the addition of environmental indicators and forestry in existing formulations of DAU.
\end{abstract}

\section{Keywords:}

ecological fiscal transfer; forestry; environment.

\begin{abstract}
Abstrak
Sejalan dengan isu peningkatan kesejahteraan di berbagai belahan dunia termasuk Indonesia, agenda pembangunan beralih dari permasalahan pemberantasan kemiskinan menjadi tujuan pembangunan berkelanjutan (Sustainable Development Goal's atau SDG's). Untuk mendukung hal tersebut, peran dari anggaran menjadi sangat signifikan, termasuk mekanisme Transfer ke Daerah. Berdasarkan analisis, mekanisme Dana Alokasi Umum (DAU) memiliki potensi menjadi sumber pendanaan lingkungan dan kehutanan melalui mekanisme ecological fiscal transfer. Mekanisme ecological fiscal transfer diwujudkan melalui penambahan pagu alokasi DAU untuk kepentingan pelestarian lingkungan dan kehutanan serta menambahkan indikator lingkungan hidup dan kehutanan dalam formulasi eksisting DAU.
\end{abstract}

\section{Kata Kunci:}

ecological fiscal transfer; kehutanan; lingkungan hidup.

\section{Pendahuluan}

Seiring dengan peningkatan kesejahteraan umat manusia di berbagai belahan dunia termasuk Indonesia, agenda pembangunan beralih dari sebelumnya difokuskan pada pemberantasan kemiskinan termasuk dampak ikutannya, sebagaimana tercantum pada tujuan pembangunan milenium (Millenium Development Goal's atau MDG's) tahun 2015 kepada tujuan pembangunan berkelanjutan (Sustainable Development Goal's atau SDG's). Sustainable development atau diistilahkan dengan

\footnotetext{
- Peneliti Pusat Kebijakan Pembiayaan Perubahan Iklim dan Multilateral, Badan Kebijakan Fiskal, Kementerian Keuangan,

Email: djohar78@gmail.com
} 
pembangunan berkelanjutan menawarkan konsep inklusif berdurasi jangka panjang dalam pengelolaan ekonomi dengan menyelaraskan pencapaian pertumbuhan ekonomi yang tinggi, pelestarian lingkungan, dan pemberdayaan sosial inklusif.

Pendekatan ekonomi ini diharapkan dapat menjadi solusi atas berbagai tantangan, ketidakadilan, dan dampak negatif dari pelaksanaan pendekatan ekonomi atau pembangunan konvensional. Dalam perjalanannya, pendekatan ekonomi berkelanjutan sering didefinisikan juga sebagai bentuk pengembangan ekonomi hijau (green economy). Implementasi sistem ekonomi hijau secara tepat, diyakini dapat memenuhi kebutuhan ekonomi generasi penduduk saat ini, tanpa mengorbankan pemenuhan kebutuhan generasi penduduk masa mendatang.

Dalam konteks pembangunan nasional, tujuan yang diharapkan dari ekonomi hijau selaras dengan empat pilar strategi pembangunan nasional, yaitu pro-growth, pro-poor, pro-job, dan pro-environment. Strategi nasional tersebut diharapkan dapat menghasilkan pertumbuhan ekonomi yang berkelanjutan, yang mampu mengatasi dan beradaptasi dengan berbagai perubahan perekonomian dan lingkungan global.

Peran Pemerintah khususnya pada pengelolaan kebijakan fiskal menjadi krusial dalam mendorong implementasi ekonomi hijau secara optimal. Melalui insentif fiskal, Pemerintah dapat mendukung investasi berwawasan lingkungan seperti energi terbarukan yang bertujuan mengatasi krisis energi dan listrik. Di sisi berlawanan, Pemerintah dengan disinsentif fiskal dapat menerapkan pajak tambahan bagi industri yang mengotori lingkungan dan kesehatan. Hal yang sama dapat dilakukan pula pada kebijakan pengeluaran anggaran melalui pengalokasian anggaran yang lebih tepat bagi pengeluaran yang mengedepankan aspek keberlanjutan.
Kebijakan fiskal Pemerintah dapat pula mendorong partisipasi sektor swasta dalam pendanaan bagi investasi ekonomi hijau. Partisipasi swasta diperlukan mengingat hampir 80 persen dari gross domestic product (GDP) berasal dari sektor swasta. Oleh karenanya, perlu adanya sinergi yang harmonis dan bisnis model yang memberikan keuntungan yang optimal bagi kedua belah pihak, pemerintah dan swasta, dalam mendukung pengembangan dan investasi ekonomi hijau di Indonesia.

Terlebih, komitmen Pemerintah dalam upaya mitigasi perubahan iklim sebagai bentuk pendekatan politik terhadap isu green economy, sudah dinyatakan secara tegas oleh Presiden melalui penyusunan Perpres No 61 Tahun 2011 tentang Rencana Aksi Nasional (RAN) Penurunan Emisi Gas Rumah Kaca (GRK). Dalam Perpres tersebut Presiden menyatakan komitmennya untuk mengurangi emisi gas rumah kaca sebesar 26 persen dengan upaya sendiri dan 41 persen dengan bantuan asing di tahun 2020.

Berdasarkan dokumen RAN GRK tersebut, diidentifikasi beberapa sektor yang menjadi penyumbang utama terjadinya emisi gas rumah kaca yang mencakup sektor kehutanan, energi dan industri, transportasi, pertanian dan lahan gambut. Untuk mengurangi emisi gas rumah kaca dari sektor kehutanan, Indonesia antara lain telah mengambil inisiatif untuk melakukan moratorium terhadap hutan, perbaikan perizinan restorasi ekosistem dan jasa lingkungan atau hasil hutan non-kayu, kegiatan demonstrasi REDD+, rehabilitasi daerah aliran sungai dan hutan kota, mangrove, hutan rakyat dan kemitraan dengan hutan rakyat, pengendalian kebakaran hutan, berkurang 20 persen dan berhasil 67 persen, peningkatan tuntutan atas perbuatan pelanggaran hukum kehutanan, pengelolaan ekosistem dan perlindungan hutan serta pelestarian hutan tanaman.

Sedangkan terkait dengan sektor energi, beberapa aktivitas yang tercatat diantaranya: 
aksi-aksi pengelolaan energi, kemitraan konservasi energi, penghematan energi rumah tangga, energi terbarukan (hidro, surya, angin, biomassa), pengembangan biogas, kendaraan berbahan bakar gas bumi dan gas cair untuk transportasi publik, gas bumi untuk rumah tangga, instalasi mini LPG serta penanaman pohon pasca penambangan. Namun demikian, dengan masih besarnya pola konsumsi masyarakat terhadap sumber energi yang berasal dari fossil fuel tentunya menjadi kendala dalam upaya pengurangan emisi dari sektor tersebut.

Dalam tataran implementasi, dukungan pembiayaan merupakan faktor yang sangat strategis untuk dapat terlaksananya kegiatan RAN atau Rencana Aksi Daerah (RAD) GRK baik yang berasal dari pemerintah melalui Anggaran Pendapatan dan Belanja Negara (APBN) dan Anggaran Pendapatan dan Belanja Daerah (APBD) serta swasta. Di dalam Peraturan Presiden (Perpres) No. 61 Tahun 2011 pasal 11 disebutkan bahwasanya RAN/RAD GRK wajib dibiayai dari APBN/APBD, swasta serta berbagai sumber pembiayaan lainnya yang tidak bertentangan dengan regulasi. Adapun sumber-sumber pembiayaan untuk RAN GRK yang berasal dari APBN antara lain diperoleh melalui pendapatan pajak, pendapatan bukan pajak, hibah dari luar negeri, dana perwalian, dan lain sebagainya.

Di lingkup daerah, sebagai bentuk turunan dari penyusunan RAN GRK, Pemerintah Provinsi kemudian wajib menyusun RAD GRK. Dengan dokumen RAD GRK ini, Pemerintah Provinsi dan Kabupaten/Kota berperan sangat penting dalam penurunan emisi GRK di daerah masing-masing sejalan dengan amanat Perpres No. 61 Tahun 2011. Nantinya kegiatan RAD GRK tersebut dapat dibiayai dari APBD serta sumber-sumber lainnya yang sah.

Persoalannya, isu greeneconomy, perubahan iklim serta pembangunan berkelanjutan belum menjadi hal yang prioritas baik di level nasional khususnya bagi pemerintah daerah.
Bagaimana mengurangi jumlah penduduk miskin, meningkatkan pendapatan daerah serta memajukan ekonomi daerah justru lebih mendominasi dibandingkan pertimbangan aspek green economy, perubahan iklim dan pembangunan berkelanjutan khususnya di level penganggaran APBD. Akibatnya dukungan pendanaan dari APBD menjadi hal yang sangat sulit diwujudkan, bahkan di daerah dengan kapasitas fiskal yang relatif tinggi sekalipun. Persoalan lainnya yang sering muncul adalah masalah dominasi belanja wajib khususnya gaji pegawai di daerah yang menyebabkan APBD tidak lagi memiliki space untuk dialokasikan dalam mengatasi isu lingkungan.

Dari sisi APBD, potensi pendanaan lingkungan dapat dilakukan melalui mekanisme transfer ke daerah yang terdiri dari Dana Bagi Hasil (DBH), Dana Alokasi Umum (DAU) dan Dana Alokasi Khusus (DAK). Masing-masing komponen tersebut memiliki tujuan yang berbeda. DBH sebagai bentuk sharing pendapatan antara pemerintah dan daerah, ditujukan untuk mengurangi dampak kesenjangan vertikal (vertical im-balances) yang pernah mengemuka di era Orde Baru.

SementaraDAUdisusunsebagaimekanisme block grant di daerah untuk memenuhi kebutuhan pelaksanaan pemerintahan, pelayanan masyarakat dan pembangunan daerah. Untuk kebutuhan pembangunan di daerah khususnya yang terkait dengan infrastruktur fisik, pemerintah mengalokasikan DAK. DAU dan DAK ini ditujukan untuk mengurangi kesenjangan horizontal (horizontal im-balances) antar daerah yang selama ini terjadi akibat ketidakmerataan kondisi di daerah.

Jika dikaitkan dengan kondisi existing, maka pendanaan DAK untuk beberapa sektor khususnya kehutanan dan lingkungan hidup memiliki potensi sebagai sumber pendanaan lingkungan di daerah. Namun sayangnya, filosofi DAK sendiri merupakan program prioritas nasional yang bersifat top down sehingga kebutuhan daerah justru 
kadang terabaikan. Selain itu, DAK Kehutanan oleh beberapa pengamat justru dianggap memberikan motivasi kepada daerah untuk melakukan deforestasi dan degradasi, karena daerah dengan tingkat kerusakan hutan yang besar justru mendapatkan alokasi dana yang besar pula. Sebaliknya daerah yang senantiasa melakukan konservasi lingkungan khususnya sektor kehutanan, justru mendapatkan alokasi yang sedikit. Akibatnya, beberapa daerah yang sebetulnya memiliki kesadaran terhadap konservasi lingkungan khususnya kehutanan merasa tidak diberikan kompensasi yang memadai atas inisiatif positif yang mereka lakukan. Pendanaan yang besar justru diberikan kepada daerah yang kurang bertanggungjawab terhadap pengelolaan sektor lingkungan khususnya kehutanan. Padahal, melakukan konservasi lingkungan khususnya kehutanan memerlukan effort yang begitu besar jika dikaitkan dengan pemenuhan kebutuhan saat ini oleh masyarakat.

Sebagai contoh misalnya pengalokasian DAK Kehutanan tahun 2014. Berdasarkan petunjuk teknis alokasi DAK Kehutanan 2014, sasaran kegiatan yang dilingkupi diantaranya: meningkatkan pengelolaan hutan produksi dan hutan lindung dengan prioritas pada areal KPHP dan KPHL melalui kegiatan penataan areal kerja KPHP/KPHL, penyediaan sarana prasarana $\mathrm{KPH}$, penyediaan sarana prasarana perlindungan dan pengamanan hutan termasuk untuk pemadaman kebakaran hutan, pengolahan hasil hutan serta penyuluhan kehutanan. Selain itu juga dilakukan upaya peningkatan pengelolaan Taman Hutan Rakyat dan Hutan Kota dengan kegiatan penanaman, penyediaan sarana prasarana perlindungan dan pengamanan hutan termasuk pemadaman kebakaran hutan serta penyuluhan kehutanan.

Merujuk pada permasalahan ini, perlu dipikirkan mekanisme lainnya di dalam bingkai Transfer ke Daerah selain DAK yang dapat digunakan untuk mendanai pengelolaan lingkungan dan kehutanan. Dilihat dari besaran alokasinya, DAU memiliki potensi sebagai sumber pendanaan yang paling memungkinkan dibandingkan DBH. APBN-P 2014 misalnya, pemerintah mengalokasikan DAU hingga Rp 341,2 triliun, meningkat signifikan menjadi Rp 349,2 triliun dalam Rancangan APBN (R-APBN) 2015. Sementara alokasi DBH dalam APBN-P 2014 sebesar Rp 117,6 triliun dan Rp 124,4 triliun dalam R-APBN 2015. Sedangkan alokasi DAK dalam APBN-P 2014 mencapai Rp 33,0 triliun dan Rp 35,8 triliun dalam R-APBN 2015.

Sayangnya, meskipun ditujukan untuk membiayai pelaksanaan fungsi pemerintahan, pelayanan masyarakat dan pembangunan di daerah, dalam implementasinya DAU justru lebih banyak terserap hingga di atas 50 persen untuk anggaran fungsi pemerintahan semata, khususnya pembayaran gaji pegawai. Akibatnya di banyak daerah, DAU menjadi identik sebagai sumber pembiayaan gaji pegawai tanpa dapat dialokasikan untuk kepentingan lainnya. Padahal di beberapa negara lain seperti Brasil, Portugal dan Jerman, mekanisme DAU dapat digunakan sebagai salah satu sumber pendanaan bagi upaya menjaga kelestarian lingkungan yang dilakukan oleh masing-masing daerah melalui konsep yang disebut ecological fiscal transfer.

Berdasarkan uraian latar belakang dan permasalahan tersebut di atas, perumusan permasalahan dalam penelitian ini adalah:

1) Bagaimana potret Dana Alokasi Umum di era otonomi daerah selama ini jika dibandingkan dengan kebutuhan pendanaan lingkungan yang ada di Rencana Aksi Daerah?

2) Bagaimana cara mengintegrasikan Dana Alokasi Umum sebagai model ecological fiscal transfer di Indonesia?

\section{Desentralisasi Fiskal dan Pendanaan di Daerah}

Dalam Riatu (2013) dijelaskan bahwa secara umum, sistem transfer dan konteks 
desentralisasi fiskal di Indonesia lebih mengarah pada competitive decentralization. Setiap tingkat pemerintahan berupaya untuk mengklaim bentuk pencapaian dan kinerja pelayanan publik. Kebijakan seperti pembagian fungsi atau kewenangan kurang berjalan, dan pada prakteknya mengarah pada birokrasi dan program yang tumpang tindih.

Rasionalisasi skema insentif transfer untuk bentuk transfer spesifik tidak hanya dapat mengkaitkan pendanaan untuk jenis kegiatan tertentu tetapi juga dapat didasarkan untuk pencapaian target dalam lingkup perencanaan. Berdasarkan rekomendasi bentuk pendanaan RAD-GRK, setidaknya terdapat dua kemungkinan pendanaan melalui mekanisme dana transfer, yaitu melalui mekanisme Hibah Daerah, dan selanjutnya melalui pengembangan skema insentif DAK.

Konteks sumber pendanaan untuk kegiatan yang sama sebenarnya tidak terlalu menjadi masalah ketika transparansi dan mekanisme monitoring pengawasan sudah built-in dan cukup mudah diketahui dan dipahami oleh berbagai pihak. Selain itu, untuk instrumen pendanaan terhadap kegiatan yang dilaksanakan oleh pemerintah daerah, efektifitas instrumen pendanaan umumnya juga terkait dengan permasalahan pembagian peran antar institusi untuk kejelasan proses monitoring atau pengawasan dan evaluasi, serta apakah instrumen pendanaan tersebut telah menjamin kejelasan akuntabilitas dari institusi pemerintah daerah untuk pelaksanaan dan keberlanjutan program yang dilakukan.

Seperti dijelaskan dalam regulasi, salah satu karakteristik dari dana hibah, adalah mekanisme evaluasi yang relatif terintegrasi dengan penyaluran dana hibah. Dalam hal ini, umumnya penyaluran dana hibah akan bergantung dari proses evaluasi kesiapan pemerintah daerah (dalam pemenuhan persyaratan hibah) dan pelaksanaan kegiatan sesuai dengan standar ataupun kesepakatan yang ada dalam perjanjian hibah.

Namun demikian, berdasarkan penerapan hibah yang ada saat ini, mekanisme pendanaan hibah cocok diterapkan apabila ditargetkan hanya untuk beberapa daerah. Konteks administrasi terutama mekanisme evaluasi yang umumnya dilakukan instansi pemerintah pusat dengan keterbatasan sumberdaya yang ada kemungkinkan berimplikasi pada kurang efektifnya penerapan Dana Hibah apabila

\section{Gambar 1.}

Sumber Pendanaan untuk Pelaksanaan Kegiatan di Daerah

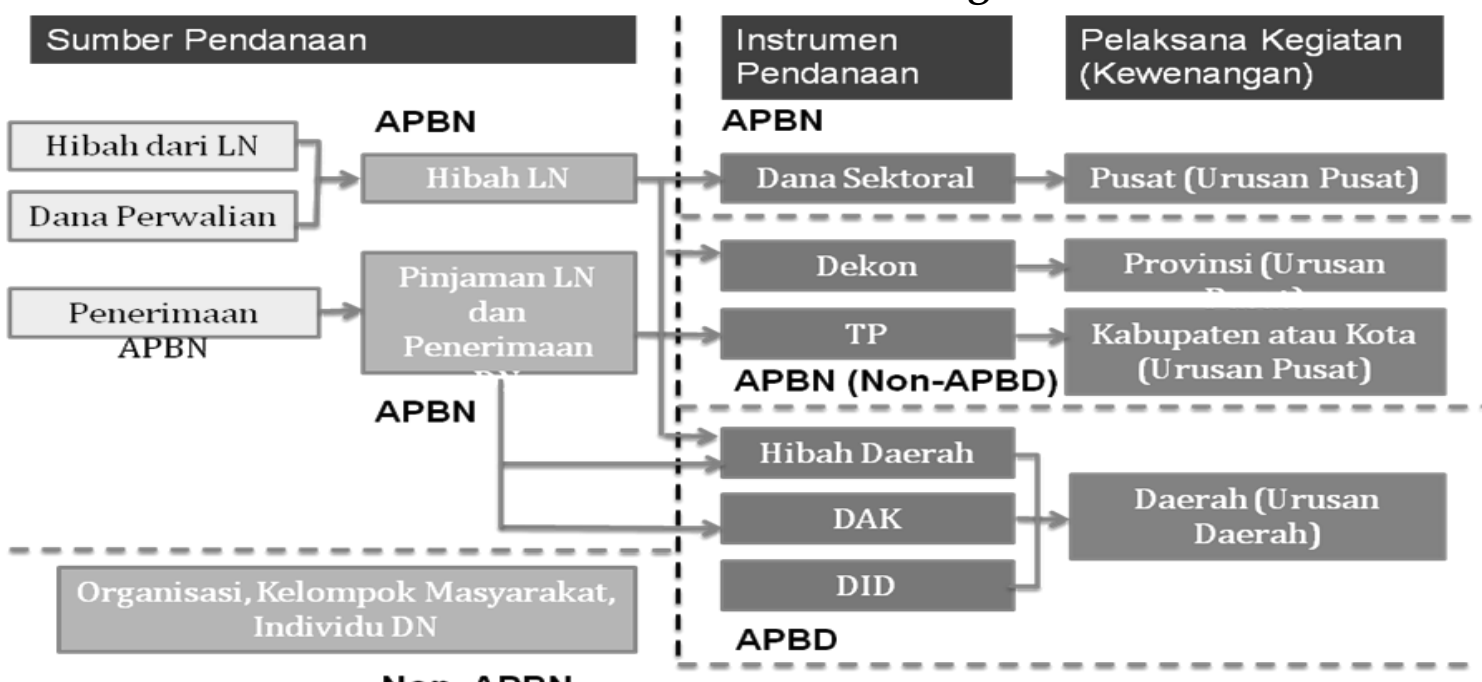

Sumber: Riatu, 2013

Non-APBN 
Dana Hibah akan ditujukan untuk jumlah pemerintah daerah yang relatif besar. Untuk itu, dalam kaitannya dengan RAD-GRK, pendanaan melalui Hibah kemungkinan dapat diterapkan apabila fokus untuk pendanaan di tingkat provinsi. Walaupun penyesuaian juga perlu dilakukan apabila, pelaksanaan kegiatan mitigasi justru akan banyak dilakukan di tingkat pemerintahan kabupaten atau kota.

Mekanisme skema insentif DAK juga dapat dilakukan untuk sektor penurunan emisi GRK yang memang sudah memiliki pendanaan DAK, dalam hal ini mengacu pada sektor kehutanan, sektor pertanian, dan sektor lingkungan hidup. Seperti tercantum di dalam regulasi, potensi penerapan skema insentif DAK, adalah untuk menyelaraskan perencanaan atau target pencapaian sektor dan kegiatan mitigasi penurunan emisi GRK di sektor terkait yang menjadi urusan pemerintah daerah.

Dari segi karakteristik pendanaan melalui DAK, yang lebih ditujukan pada aktivitas yang bersifat fisik, serta fokus kegiatan umumnya adalah kegiatan yang dilakukan dan menjadi urusan pemerintah tingkat kabupaten dan kota, maka konteks pendanaan melalui DAK juga berfungsi komplementer dari pendanaan melalui Dana Hibah, terutama apabila Dana Hibah yang didasarkan pada dokumen RADGRK lebih mengacu pada kegiatan yang dilakukan oleh pemerintah provinsi.

Untuk skema insentif DAK, contoh skema insentif yang sudah diterapkan adalah dalam konteks Proyek Pemerintah Daerah dan Desentralisasi (P2D2). Insentif dari P2D2 bertujuan agar pemerintah daerah dapat melakukan proses reporting atau pelaporan, monitoring dan evaluasi yang dapat dilakukan terkait dengan DAK. Apabila RAD-GRK diterapkan melalui mekanisme DAK dengan skema insentif P2D2, maka mekanisme penyaluran insentif sebaiknya juga dilakukan sebagai bagian dari pool DAK sektor terkait, dan juga jadwal verifikasi yang dapat dipercepat untuk periode sebelum APBD-P.
Selama lima tahun terakhir, DAK yang disalurkan oleh pemerintah pusat rata-rata mengalami peningkatan sebesar 18.5 persen, walaupun fluktuasi perubahan alokasi cukup tinggi setiap tahun-nya. Terkait dengan skema insentif DAK, diperlukan kepastian bahwa untuk sektor yang juga akan atau telah mencakup kegiatan mitigasi emisi GRK, setidaknya peningkatkan pagu alokasi tidak melebihi dari rata-rata peningkatan pagu DAK secara agregat ini. Misalnya, jika mengadopsi skema P2D2 untuk pool of fund, maka untuk sektor DAK yang terkait dengan mitigasi, setidaknya terdapat tambahan 10 persen dari total pagu sektor terkait.

\section{Dana Alokasi Umum}

BerdasarkanBuku Pegangan Desentralisasi Fiskal tahun 2008, disebutkan bahwa Dana Alokasi Umum merupakan transfer dari Pemerintah Pusat yang penggunaannya diserahkan secara penuh kepada Pemerintah Daerah. Berdasarkan pasal 1 Undang-undang Nomor 25 Tahun 1999 yang kemudian direvisi dalam UU Nomor 33/2004 dijelaskan bahwa Dana Alokasi Umum, selanjutnya disebut DAU adalah dana yang bersumber dari pendapatan APBN yang dialokasikan dengan tujuan pemerataan keuangan antar-Daerah untuk mendanai kebutuhan Daerah dalam rangka pelaksanaan Desentralisasi. Desentralisasi mengandung pengertian penyerahan wewenang pemerintahan oleh Pemerintah Pusat kepada daerah otonom untuk mengatur dan mengurus urusan pemerintahan dalam sistem Negara Kesatuan Republik Indonesia. Implikasinya, DAU dialokasikan kepada setiap daerah dalam rangka menjalankan kewenangan Pemerintah Daerah dalam memberikan pelayanan publik kepada masyarakat.

Secara umum, formula perhitungan DAU terdiri dari dua komponen utama yaitu Alokasi Minimum (AM) dan Alokasi DAU berdasarkan Kesenjangan Fiskal (AKF). Komponen Alokasi Minimum terdiri dari komponen Lumpsum 


\section{Gambar 2.}

\section{Bentuk Umum Formula DAU}

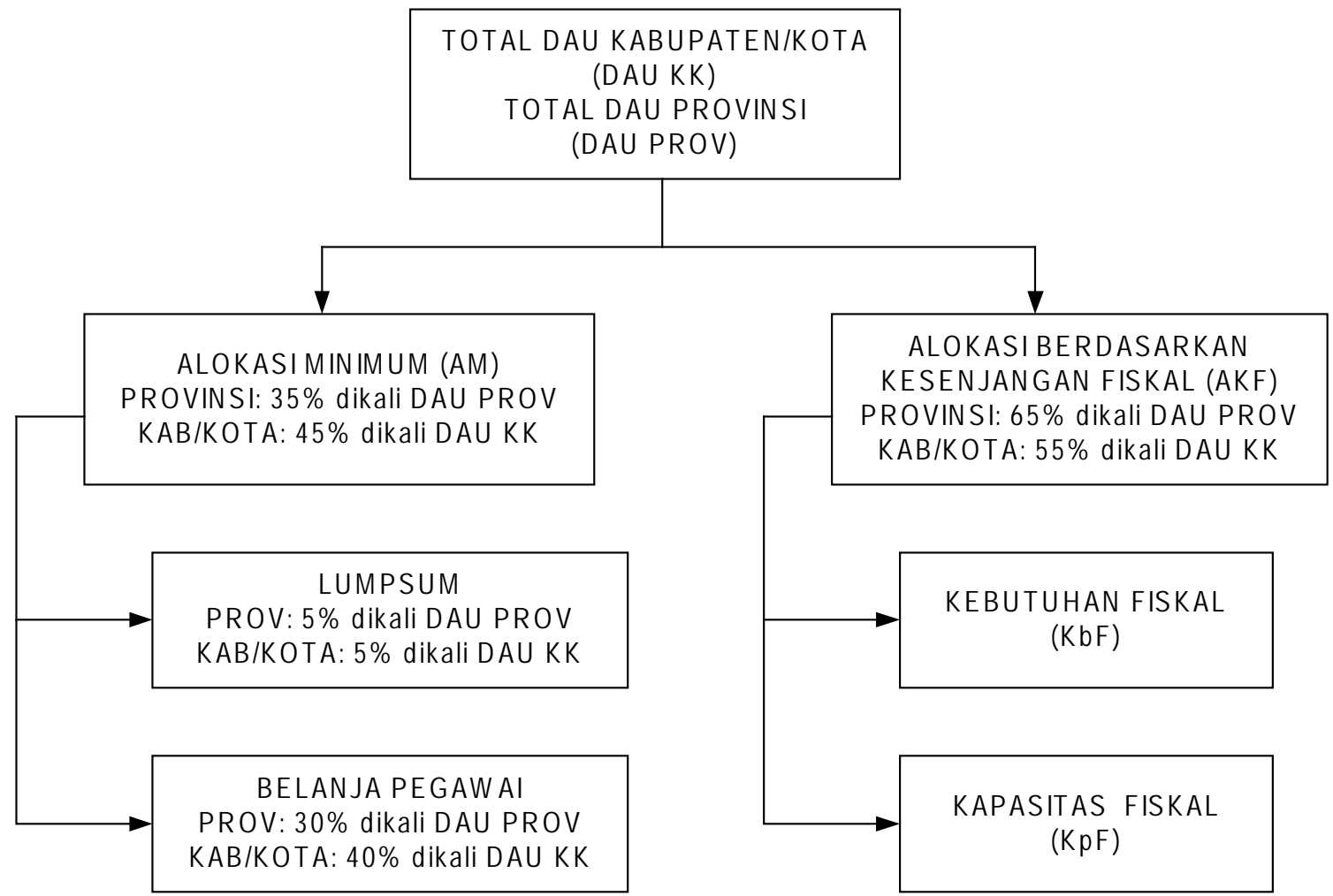

Sumber: DJPK, 2008

dan belanja pegawai, sedangkan alokasi DAU ditentukan berdasarkan kesenjangan fiskal yang diperoleh dari perhitungan kebutuhan dan kapasitas fiskal atas masing-masing fiskal. Dalam perkembangannya, proporsi komponen Alokasi Minimum dan Alokasi berdasarkan Kesenjangan Fiskal berbeda bobotnya untuk Kabupaten/Kota dan Provinsi. Hal ini memberikan informasi pula bahwa alokasi DAU untuk Kabupaten/Kota dan Provinsi dilakukan secara terpisah. Pada tahun 2004, dari total DAU Provinsi bobot AM sebesar 35 persen serta bobot AKF sebesar 65 persen. Namun, di tingkat Kabupaten/Kota, bobot AM itu sebesar 45 persen dan bobot AKF sebesar 55 persen. Jumlah total untuk setiap komponen DAU ini lah yang akan dibagikan kepada masing-masing provinsi dan Kabupaten/Kota. Gambaran umum tentang formula DAU dan bobot setiap komponen untuk Kabupaten/
Kota dan provinsi pada tahun 2004 dapat ditunjukkan pada Gambar 2.

Proses selanjutnya yang akan dilakukan adalah membagi DAU total provinsi dan Kabupaten/Kota kepada masing-masing provinsi dan Kabupaten/Kota. Pembagian kepada masing-masing daerah ini juga akan terdiri dari setiap komponen. Proses perhitungan tersebut dilakukan dengan membagi Alokasi Minimum dan Alokasi berdasarkan Kesenjangan Fiskal secara total kepada setiap daerah. Pada bagian ini, akan ditunjukkan proses pembagian total Alokasi Minimum dalam DAU kepada masing-masing daerah.

Pembagian total AM ini akan ditunjukkan berdasarkan setiap komponennya. Komponen pertama adalah lumpsum. Sesuai dengan namanya, komponen lumpsum ini dibagi secara rata-rata kepada masing-masing 
daerah. Lebih jauh, komponen ini tidak sejalan dengan semangat dari DAU sebagai alat untuk pemerataan antar daerah berdasarkan fiscal gap. Proses perhitungan lumpsum setiap daerah ini secara sederhana dapat ditunjukkan pada rumusan: lumpsum setiap daerah = jumlah lumpsum total/jumlah daerah. Pembagian alokasi DAU Provinsi dan Kabupaten/Kota dilakukan secara terpisah secara proporsi, sehingga terdapat dua formula yang berbeda dalam perhitungan lumpsum ini baik dari sisi jumlah total lumpsum dan jumlah daerahnya.

Komponen kedua dari Alokasi Minimum ini adalah komponen Belanja Pegawai. Pembagian komponen Belanja Pegawai ini kepada masing-masing daerah secara prinsip berdasarkan data proporsi belanja pegawai yang dikalikan dengan jumlah total alokasi DAU dari komponen belanja pegawai. Dalam bentuk formula, pembagian alokasi DAU dari komponen Belanja Pegawai kepada masingmasing daerah dapat ditunjukkan sebagai berikut: Alokasi DAU dari komponen belanja pegawai daerah $Z$ = belanja pegawai daerah $\mathrm{Z}$ /total belanja pegawai seluruh daerah $\mathrm{x}$ Total alokasi DAU dari komponen belanja pegawai.

\section{Pembangunan Berkelanjutan di Indonesia.}

Bali Roadmap merupakan titik awal dalam membangun kerangka komitmen mengatasi dampak perubahan iklim secara penuh, efektif dan berkelanjutan, melalui pengurangan emisi dan deforestasi di negaranegara berkembang, serta operasionalisasi Mekanisme Pembangunan Bersih. Semenjak itu pula perhatian Indonesia pada pembangunan berkelanjutan Indonesia mulai dikelola secara serius. Pengertian pembangunan berkelanjutan di Indonesia disebutkan dalam Undang-Undang Nomor 32 tahun 2009 tentang Perlindungan dan Pengelolaan Lingkungan Hidup, yaitu upaya sadar dan terencana yang memadukan aspek lingkungan hidup, sosial, dan ekonomi ke dalam strategi pembangunan untuk menjamin keutuhan lingkungan hidup serta keselamatan, kemampuan kesejahteraan, dan mutu hidup generasi masa kini dan generasi masa depan.

Agenda 21 pada April 1995 menyusun 134 indikator pembangunan berkelanjutan dalam kerangka kerja Tekanan, Keadaan/Dampak, dan Respon (FSR Framework). Dari ke 134 indikator tersebut terdapat 27 prinsip, sedangkan Indonesia hanya mengadopsi beberapa prinsip yang kiranya dapat diimplementasikan, prinsip-prinsip tersebut antara lain:

a) Pelayanan Masyarakat;

- Pengentasan rakyat miskin;

- Perubahan pola konsumsi;

- Dinamika penduduk;

- Pengelolaan dan peningkatan kesehatan;

- Pengembangan perumahan dan pemukiman;

- Sistem perdagangan global, instrumen ekonomi serta neraca ekonomi dan lingkungan terpadu.

b) Pengelolaan limbah

- Perlindungan atmosfer;

- Pengelolaan bahan kimia beracun;

- Pengelolaan limbah bahan berbahaya dan beracun;

- Pengelolaan limbah padat dan cair;

- Pengelolaan limbah dan radio aktif.

c) Pengelolaan sumber daya tanah

- Perencanaan sumber daya tanah;

- Pengembangan pertanian dan wilayah pedesaan;

- Pengelolaan hutan;

- Pengelolaan sumber daya air.

d) Pengelolaan sumber daya alam

- Konservasi keanekaragaman hayati;

- Pengembangan bio-teknologi

- Pengelolaan wilayah pesisir dan laut

Meskipun dalam prinsip tersebut titik berat yang diutamakan adalah aspek lingkungan. Prinsip-prinsip di atas telah menggambarkan bahwa aspek sosial dan 
ekonomi juga merupakan bagian penting dari prinsip pembangunan berkelanjutan (Nurcholis, 2013).

\section{Ecological Fiscal Transfer untuk Level Provinsi di Indonesia}

Penelitian mengenai mekanisme Ecological Fiscal Transfer di Indonesia pernah dilakukan oleh Mumbunan, Sonny; Ring, Irene; Lenk, Thomas (2012): Ecological fiscal transfers at the provincial level in Indonesia, UFZ-Diskussionspapiere, No. 06/2012. Dalam penelitian tersebut disebutkan bahwa sebuah wilayah konservasi lingkungan yang menghasilkan banyak manfaat ekologi, sering memiliki kebutuhan fiskal yang relatif lebih tinggi karena biaya yang dibutuhkan untuk menjaga konservasi lingkungannya. Karenanya dibutuhkan adanya keberpihakan dari sisi penganggaran khususnya pendanaan dari pemerintah ke daerah.

Ada sejumlah pilihan kebijakan yang dapat digunakan untuk mengakomodasi kepentingan konservasi lingkungan tersebut dalam skema pendanaan melalui sistem transfer fiskal antara pemerintah dengan daerah. Dilihat dari kasus di negara lain, hingga saat ini hanya Brasil dan Portugal yang sukses menerapkan indikator ekologi secara eksplisit masuk di dalam perhitungan distribusi transfer fiskal dari pemerintah ke daerah masing-masing.

Di sejumlah negara lain, seperti Jerman, Swiss dan India, metode ecological fiscal transfer ini telah diusulkan sebagai instrumen yang cocok untuk memperhitungkan biaya lokal dan manfaat spillover dari konservasi keanekaragaman hayati. Penelitian ini kemudian mencoba melihat potensi pendanaan DAU dengan memasukkan indikator ekologi eksplisit dalam formulasi fiskal Indonesia yang berasal kebutuhan fiskal. Selain menyajikan dimensi sosial ekonomi kawasan hutan lindung sebagai proksi untuk dimensi ekologi yang memenuhi kondisi yang diperlukan untuk kebutuhan fiskal dan dimasukkan ke dalam sistem transfer fiskal yang ada, kajian ini juga bermaksud untuk mengetahui dampak baru transfer fiskal ekologi pada konfigurasi distribusi dana di daerah serta melihat efek pemerataan di level provinsi. Hasil penelitian kajian ini menunjukkan bahwa dibandingkan dengan skenario baseline transfer DAU tahun 2007, transfer fiskal dengan memasukkan indikator ekologi akan menguntungkan sepertiga provinsi di Indonesia. Dari sisi pemerataan, hasil penghitungan dengan memasukkan indikator ekologi menjadikan DAU lebih merata dibandingkan alokasi yang eksisting saat ini.

\section{Metode Penelitian}

Penelitian ini sebagian besar menggunakan data sekunder yang didapatkan dari beberapa instansi pemerintah. Secara umum jenis data yang digunakan dapat dilihat pada Tabel 1.

Berdasarkan data tersebut, nantinya akan digunakan sebagai input dalam melakukan analisis kelayakan DAU sebagai salah satu instrumen pendanaan perubahan iklim, green economy dan pembangunan berkelanjutan di daerah.

Tabel 1.

Jenis Data

\begin{tabular}{cll}
\hline No & \multicolumn{1}{c}{ Data } & \multicolumn{1}{c}{ Instansi } \\
\hline 1 & Data Realisasi DAU per Provinsi & Direktorat Jenderal Perimbangan Keuangan \\
2 & Data Formulasi DAU & Direktorat Jenderal Perimbangan Keuangan \\
3 & Dokumen RAD GRK & Sekretariat Perubahan Iklim, Bappenas \\
4 & Data Realisasi Transfer ke Daerah & Direktorat Jenderal Perimbangan Keuangan \\
\hline
\end{tabular}

Sumber: peneliti, data diolah 
Grafik 1.

Realisasi Transfer ke Daerah

\section{Rp Triliun}

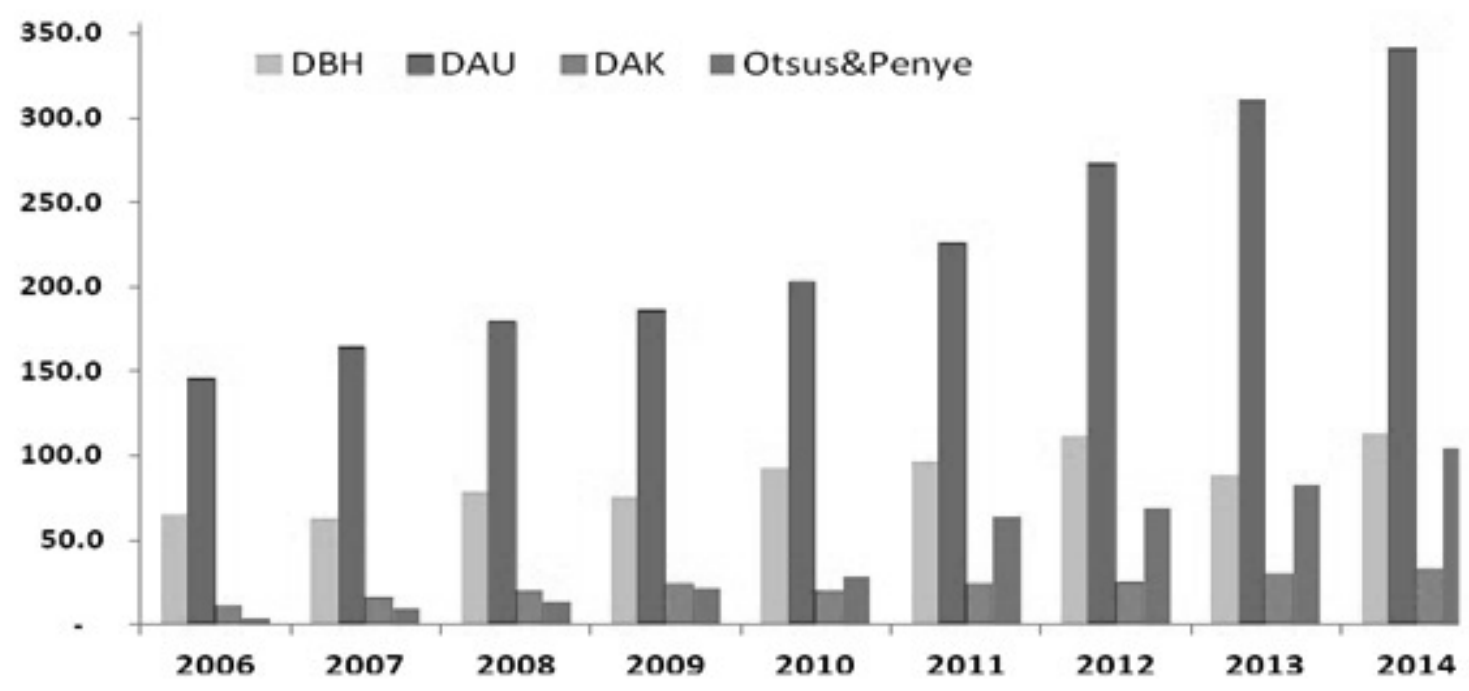

Sumber: DJPK, Kemenkeu

\section{Jenis Penelitian dan Metode Analisis}

Secara umum, jenis penelitian yang dilakukan adalah penelitian kualitatif dengan membandingkan beberapa ketentuan di dalam regulasi terkait formulasi DAU sebagai model ecological fiscal transfer yang akan direkomendasikan. Analisis kuantitatif juga dilakukan dalam bentuk statistika deskriptif untuk menggambarkan potensi dan feasibilitas DAU sebagai instrumen pendanaan lingkungan di daerah.

Instrumen analisis yang digunakan nantinya sebagian besar berupa tabel, gambargambar dan grafik untuk memberikan pemahaman di dalam analisis yang dilakukan hingga mendapatkan dasar rekomendasi bagi pemerintah. Metode analisis juga menggunakan perbandingan kelemahan dan keunggulan dari masing-masing mekanisme sumber-sumber pendanaan yang ada di daerah.

\section{Potret DAU di Era Otonomi Daerah} Dibandingkan Kebutuhan Pendanaan RAD

Jika mengacu kepada Undang-Undang Nomor 32 Tahun 2004 tentang Pemerintahan Daerah yang telah direvisi menjadi Undang-
Undang Nomor 23 Tahun 2014 serta UndangUndang Nomor 33 Tahun 2004 tentang Perimbangan Keuangan Antara Pemerintah Pusat dan Pemerintahan Daerah, mekanisme hubungan dalam sistem pendanaan Pemerintah Pusat dan Daerah diatur dalam mekanisme Transfer ke Daerah. Mekanisme ini memiliki tujuan mengurangi vertical imbalances antara Pemerintah Pusat dan Daerah serta horizontal imbalances antar Pemerintah Daerah.

Transfer ke Daerah sendiri terdiri dari komponen Dana Perimbangan (Daper) serta Dana Otonomi Khusus (Otsus) dan Dana Penyesuaian. Daper sendiri terdiri dari alokasi Dana Bagi Hasil (DBH) Sumber Daya Alam (SDA) dan Pajak, Dana Alokasi Umum (DAU) serta Dana Alokasi Khusus (DAK). Secara umum besaran alokasi Transfer ke Daerah ini terus meningkat secara signifikan setiap tahunnya seperti dalam grafik 1 .

Berdasarkan grafik 1. dapat dilihat bahwa alokasi DAU sangat mendominasi komponen Transfer ke Daerah setiap tahunnya, serta menunjukkan tren kenaikan dari tahun 2006 hingga 2014. Dilihat dari sisi keberlanjutan, secara regulasi DAU diatur besarannya dalam 


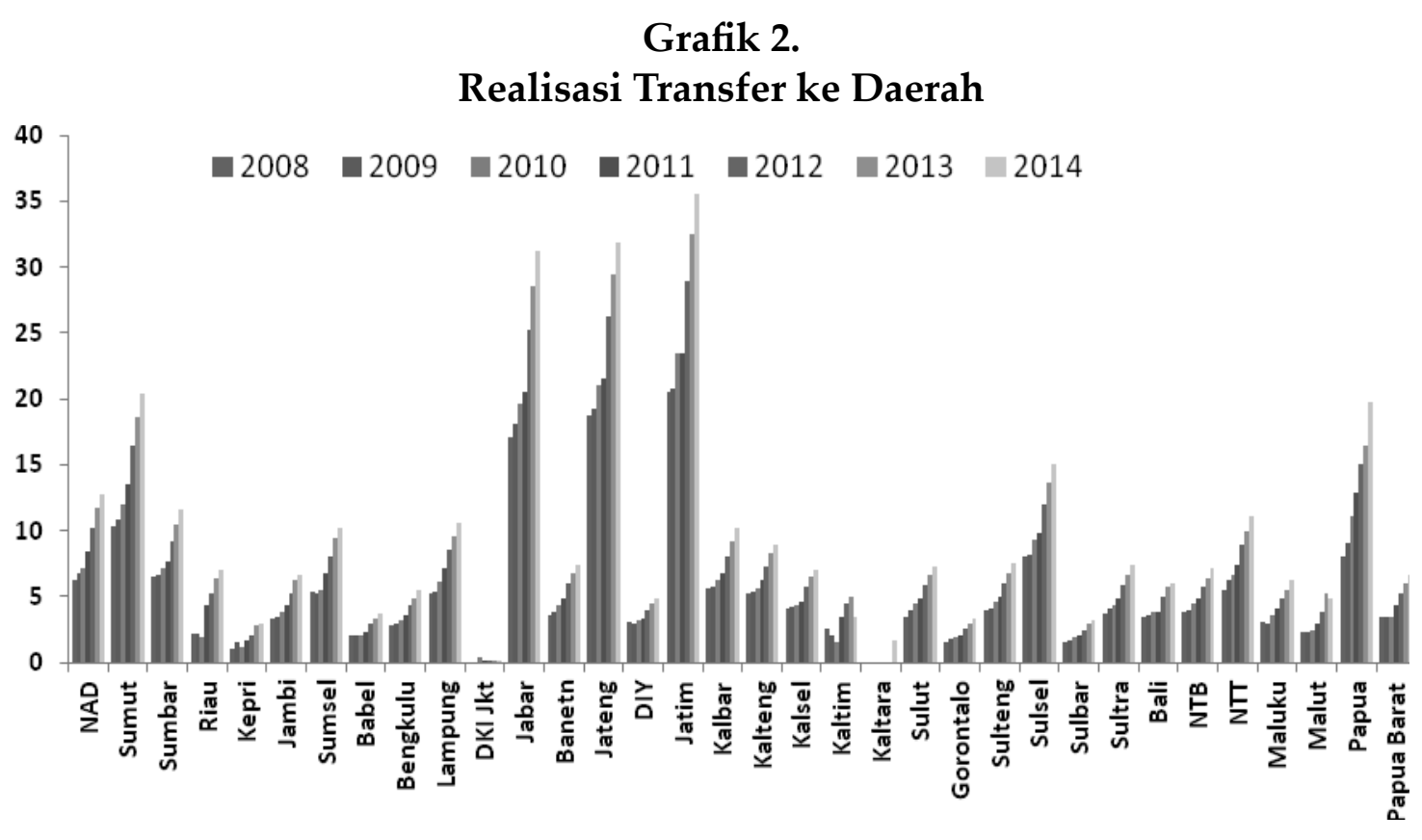

Sumber: DJPK, Kemenkeu

UU Nomor 33 Tahun 2004. Artinya pemerintah setiap tahunnya wajib mengalokasikan DAU kepada daerah dalam bingkai pelaksanaan desentralisasi fiskal. DAU juga menjadi indikator utama keberhasilan kebijakan desentralisasi fiskal itu sendiri. Berdasarkan fakta dan kondisi tersebut, dapat dilihat bahwa mekanisme DAU sangat berpotensi untuk dijadikan sumber pendanaan perubahan iklim, green economy serta pembangunan berkelanjutan di daerah, dibandingkan alokasi DAK, DBH dan Dana Otsus Penyesuaian.

Dilihat dari alokasi masing-masing provinsi, maka besaran DAU berbeda-beda sesuai dengan kapasitas fiskal dari masingmasing daerah, sesuai grafik 2 .

Meskipun menggunakan formulasi, karena indikator jumlah penduduk memiliki bobot yang paling besar, akibatnya alokasi DAU banyak terserap di daerah-daerah yang padat penduduknya khususnya di beberapa provinsi di Pulau Jawa. Provinsi Jawa Timur tercatat sebagai daerah penerima alokasi DAU terbesar setiap tahunnya dari 2008 hingga 2014, disusul Provinsi Jawa Tengah dan Jawa Barat.

Beberapa daerah di luar Pulau Jawa yang menerima alokasi DAU relatif signifikan diantaranya Provinsi Sumatera Utara, Provinsi Sulawesi Selatan serta Provinsi Papua. Dilihat dari aspek keadilan, beberapa pihak terutama daerah-daerah yang memiliki luas wilayah besar denganjumlah penduduk kecil mempertanyakan kondisi ini. Menurut mereka kurang adil jika indikator jumlah penduduk mendapatkan bobot terbesar jika akhirnya DAU justru lebih terserap hanya di daerah di Pulau Jawa yang memiliki kondisi infrastruktur lebih memadai.

Sementara itu berdasarkan laporan Sekretariat RAN/RAD, kebutuhan pendanaan RAD di daerah yang sudah disampaikan oleh 32 provinsi, mencapai sekitar Rp 200 triliun hingga tahun 2020. Dengan mendasarkan analisis di tahun 2014, maka kebutuhan tersebut dapat diturunkan menjadi $\operatorname{Rp} 33,3$ triliun setiap tahunnya secara nasional. Dilihat dari kebutuhan sektoral, energi dan transportasi, pengelolaan limbah serta kehutanan dan lahan gambut menjadi sektor terbesar dengan kebutuhan masing-masing mencapai Rp 76,8 triliun, Rp 46,1 triliun serta Rp 17,4 triliun. Beberapa proyek RAD di daerah yang sudah siap seperti pada Tabel 2.

Secara umum beberapa gambaran terkait proyek dan kegiatan RAD di daerah daintaranya: 
Tabel 2.

\begin{tabular}{clll}
\hline No & \multicolumn{1}{c}{ Nama Daerah } & \multicolumn{1}{c}{ Sektor } & \multicolumn{1}{c}{ Kebutuhan } \\
\hline 1 & Provinsi Kaltim, DI Yogyakarta (DIY), Jateng, Sumut & Energi dan Transportasi & Rp26,5 triliun \\
2 & Provinsi Sumsel & Pengelolaan Limbah & Rp543 miliar \\
3 & Provinsi Jatim & Pertanian & Rp3 miliar \\
4 & Provinsi Sulteng & Kehutanan \& Lahan Gambut & Rp2,7 triliun \\
\hline
\end{tabular}

Sumber: Sekretariat RAN/RAD, 2013

1) Proyek RAD di Provinsi Kalimantan Timur terkait dengan pencegahan alih fungsi lahan yang terjadi begitu masif. Perlu dicatat bahwa luas kawasan hutan meliputi 40,43 persen dari luas Provinsi Kalimantan Timur secara keseluruhan. Kawasan hutan ini terdiri dari hutan konservasi seluas 714,416 hektar, hutan lindung seluas 760,523 hektar serta kawasan hutan produksi seluas 2.941,698 hektar. Proyek yang sama terkait pengelolaa hutan konservasi juga menjadi prioritas bagi Pemerintah Provinsi Sumatera Selatan dan Sulawesi Tengah

a. Kegiatan yang sedikit berbeda dilakukan oleh Pemerintah Provinsi Daerah Istimewa Yogyakarta (DIY) yang lebih menitikberatkan kepada persoalan pengelolaan sektor transportasi yang terintegrasi dan berkelanjutan. Hal ini disebabkan oleh peningkatan aktivitas transportasi. Peningkatan ini sendiri diakibatkan oleh pertumbuhan kendaraan bermotor yang memicu permasalahan tundaan sampai dengan kemacetan lalu lintas pada ruas-ruas jalan di Provinsi DIY.

b. Sementara itu, Pemerintah Provinsi Jawa Tengah justru memfokuskan diri untuk mengatasi permasalahan yang terkait dengan sektor energi, sampah dan industri. Untuk sektor energi, porsi penggunaan bahan bakar fossil fuel dirasa sangat berlebihan sehingga menimbulkan dampak kerusakan lingkungan yang cukup mengkhawatirkan. Untuk sektor pengelolaan sampah, masih banyak sampah yang tidak terangkut masih menjadi persoalan utama disamping model pengelolaan yang masih bersifat tradisional. Sedangkan permasalahan di sektor industri muncul dan berkembang seiring dengan meningkatnya jumlah pelaku industri dalam kurun waktu 10 tahun terakhir baik dari sisi starting bisnis industri hingga persoalan pengelolaan limbah industrinya.

Berdasarkan analisis potret DAU dan kebutuhan RAD tersebut, dapat dilihat jika pemerintah mampu mengambil kebijakan 10 persen saja proporsi DAU dialokasikan untuk pendanaan lingkungan, maka kebutuhan Rp 33,3 triliun setiap tahunnya akan dapat di atasi demi mencapai target pengurangan emisi GRK sebesar 26 persen di tahun 2020. Menurut data terbaru yang dikeluarkan oleh Bappenas terkait besaran dana publik khususnya APBD yang sudah dikeluarkan untuk mengatasi persoalan lingkungan dan kehutanan mencapai kisaran Rp 8,7 triliun.

\section{Integrasi DAU sebagai Model Ecological Fiscal Transfer di Indonesia}

Terdapat beberapa cara untuk mengintegrasikan model ecological fiscal transfer di Indonesia. Cara yang pertama adalah menambahkan sumber alokasi pendanaan DAU untuk kemudian diberikan kepada daerah yang memiliki keperdulian dalam memelihara kelestarian lingkungannya. Brazil menjadi contoh terdepan dalam model integrasi ecological fiscal transfer seperti ini. Dengan mengalokasikan 10 persen Pajak Pertambahan 
Nilai (PPN) yang awalnya dipungut Pemerintah Pusat untuk kemudian dialokasikan ke dana daerah, Brazil menggunakan indikator luas tutupan hutan sebagai penentu besaran alokasi. Untuk daerah yang masih memiliki luas tutupan hutan yang tinggi akan mendapatkan alokasi anggaran yang lebih besar dibandingkan daerah dengan luas tutupan hutan rendah.

Jika ecological fiscal transfer model Brasil ini ingin diterapkan dalam kasus pengalokasian DAU di Indonesia, maka mekanisme yang dapat ditempuh adalah menambah besaran alokasi DAU yang awalnya dipatok 26 persen dari Pendapatan Dalam Negeri (PDN) Neto. Namun demikian, dalam perkembangannya besaran pagu alokasi DAU Nasional ini terus mengalami peningkatan. APBN 2015 sudah diexercise dengan menggunakan besaran pagu DAU sebesar 27 persen dari PDN Neto. Namun persoalan yang dihadapi dalam pengalokasian DAU justru bukan karena sumber dananya yang terbatas, namun persoalan kualitas dari pemanfaatan dana DAU tersebut.

Di banyak daerah, alokasi DAU hampir di atas 50 persen hanya dihabiskan untuk belanja PNS di daerah. Akibatnya alokasi dana DAU tidak memberikan dampak yang signifikan dalam mempercepat pembangunan dan pertumbuhan ekonomi di daerah. Oleh para ahli, untuk mengatasi permasalahan tersebut solusi yang perlu dijalankan adalah menghilangkan ketetapan besaran alokasi minimal (AD) pembayaran gaji pegawai di dalam formulasi penghitungan DAU. Di dalam draft revisi UU Nomor 33 Tahun 2004, usulan mengenai penghapusan AD belanja gaji PNSD menjadi rujukan utama untuk didiskusikan.

\section{Memasukkan Indikator Formula DAU}

Alternatif mekanisme yang dapat dilakukan dalam upaya mengintegrasikan ecological fiscal transfer dalam skema DAU adalah memasukan indikator lingkungan dalam konsep Kesenjangan Fiskal (Fiscal Gap) untuk menambah beberapa indikator kependudukan dan kewilayahan yang sudah ada sebelumnya. Hingga kini, beberapa indikator yang sudah diakomodasi di dalam perhitungan Fiscal Gap dari sisi kebutuhan fiscal (Fiscal Need) adalah:

a) Jumlah Penduduk;

b) Luas Wilayah;

c) Indeks Kemiskinan;

d) Indeks Kemahalan Konstruksi;

e) Indeks Pembangunan Manusia;

Untuk kepentingan menambahkan indikator ecological fiscal transfer ini, kita dapat melihatbeberapaindikatoryang sudah digunakan sebagai kriteria teknis di dalam alokasi DAK Lingkungan Hidup dan Kehutanan.

Berdasarkan analisis di atas, calon indikator yang memenuhi kriteria sebagai ecological fiscal transfer dengan mengacu kepada best practice di beberapa negara internasional adalah Luas Tutupan Lahan Terhadap Total Area Kritis. Daerah yang memenuhi indeks Luas Tutupan Lahan Terhadap Total Area Kritis tinggi, akan mendapatkan tambahan alokasi DAU lebih besar dibandingkan daerah dengan indeks Luas Tutupan Lahan Terhadap Total Area Kritis yang kecil. Hal ini dimaksudkan sebagai salah satu mekanisme reward kepada daerah untuk berlomba-lomba mendukung kegiatan konservasi hutan dan lingkungan di daerah masing-masing.

Dasar pertimbangan lainnya adalah untuk daerah yang tingkat degradasi dan deforestasi hutannya sudah memprihatinkan, mereka sudah mendapatkan alokasi besar melalui mekanisme DAK khususnya DAK Kehutanan. Dengan demikian, ke depannya Indonesia memiliki mekanisme yang sempurna baik yang sifatnya mendukung upaya reboisasi daerah melalui mekanisme DAK serta reward kepada daerah melalui mekanisme DAU, sehingga harapannya daerah akan berlombalomba dalam menyelenggarakan kegiatan konservasi lingkungan hidup dan kehutanan masing-masing. 
Tabel 3.

Kriteria Teknis DAK Lingkungan Hidup

\begin{tabular}{|c|c|c|c|}
\hline No & Jenis Data & & Bobot \\
\hline 1. & Kepadatan Penduduk & & $10 \%$ \\
\hline 2. & Jumlah Panjang Sungai & & $10 \%$ \\
\hline 3. & Luas Tutupan Lahan Terhadap Total Area Kritis & & $10 \%$ \\
\hline 4. & Jumlah Volume Sampah Per Tahun & & $5 \%$ \\
\hline 5. & Luas Ruang Terbuka Hijau & & $5 \%$ \\
\hline 6. & Bentuk Kelembagaan Lingkungan Hidup & & $10 \%$ \\
\hline \multirow[t]{7}{*}{7.} & Pelaporan DAK Bidang Lingkungan Hidup & & \\
\hline & a. Laporan DAK Triwulan I & $10 \%$ & \\
\hline & b. Laporan DAK Triwulan II & $10 \%$ & \\
\hline & c. Laporan DAK Triwulan III & $10 \%$ & $45 \%$ \\
\hline & d. Laporan DAK Triwulan IV & $10 \%$ & \\
\hline & e. Laporan SLHD & $30 \%$ & \\
\hline & f. Laporan DAK AkhirTahun & $30 \%$ & \\
\hline 8. & Jumlah Industri Menengah dan Besar & & $5 \%$ \\
\hline
\end{tabular}

Sumber: Kemenkeu

Tabel 4.

Kriteria Teknis DAK Kehutanan Provinsi

\begin{tabular}{|c|c|c|c|}
\hline \multirow{2}{*}{ No. } & \multirow{2}{*}{ Jenis Data } & \multicolumn{2}{|c|}{ Bobot } \\
\hline & & Luar Jawa dan DIY & Jawa (selain DIY) \\
\hline 1. & Operasionalisasi Kesatuan Pengelolaan Hutan (KPH) & $60 \%$ & - \\
\hline 2. & Pengembangan Taman Hutan Rakyat (Tahura) & $40 \%$ & $100 \%$ \\
\hline
\end{tabular}

Sumber: Kemenkeu

Tabel 5.

Kriteria Teknis DAK Kehutanan Kabupaten/Kota

\begin{tabular}{|c|c|c|c|c|}
\hline \multirow[b]{2}{*}{ No } & \multirow[b]{2}{*}{ Jenis Data } & \multicolumn{3}{|r|}{ Bobot } \\
\hline & & Luar Jawa & Jawa & $\begin{array}{c}\text { Bali, NTB, NTT, Maluku, } \\
\text { Maluku Utara, Papua, dan } \\
\text { Barat }\end{array}$ \\
\hline 1. & Operasionalisasi Kesatuan Pengelolaan Hutan (KPH) & $40 \%$ & - & $55 \%$ \\
\hline 2. & Pengembangan dan Peningkatan Hutan Rakyat & $20 \%$ & $50 \%$ & $30 \%$ \\
\hline 3. & Perlindungan dan Pengamanan Hutan & $30 \%$ & $30 \%$ & - \\
\hline 4. & Pengembangan Hutan Kota & $10 \%$ & $20 \%$ & $15 \%$ \\
\hline
\end{tabular}

Sumber: Kemenkeu

\section{Kesimpulan}

a) Berdasarkan analisis, mekanisme Transfer ke Daerah sebetulnya memiliki peran yang signifikan dalam mendukung upaya pelestarian lingkungan khususnya sektor kehutanan;

b) Mekenisme DAK dapat digunakan sebagai kebijakan yang sudah eksisting dalam mendukung upaya reboisasi dan perbaikan lingkungan di daerah. Sayangnya mekanisme tersebut memiliki banyak keterbatasan;

c) Sebaliknya mekanisme DAU berpotensi digunakan sebagai mekanisme insentif dan reward kepada daerah untuk menjaga dan melindungi lingkungan hidup khususnya sektor kehutanan dalam bentuk ecological fiscal transfer; 
d) Mekanisme ecological fiscal transfer dapat diwujudkan melalui upaya menambah besaran alokasi DAU yang diarahkan untuk kegiatan lingkungan hidup dan kehutanan serta menambah indikator di dalam formulasi perhitungan DAU;

e) Calon indikator yang paling signifikan untuk membentuk ecological fiscal transfer adalah Luas Tutupan Lahan Terhadap Total Area Kritis;

f) Daerah dengan Luas Tutupan Lahan Terhadap Total Area Kritis tinggi maka akan mendapatkan alokasi DAU yang lebih besar dibandingkan daerah dengan Luas Tutupan Lahan Terhadap Total Area Kritis kecil;

\section{Saran}

a) Rekomendasi bagi Pemerintah Pusat : memasukkan agenda ecological fiscal transfer ke dalam mekanisme revisi Undang-undang Nomor 33 Tahun 2004 tentang Perimbangan Keuangan Antara Pemerintah Pusat dan Pemerintahan Daerah khususnya terkait dengan formulasi kebijakan DAU secara nasional;

b) Rekomendasi bagi Pemerintah Daerah: memasukkan agenda ecological fiscal transfer ke dalam penyusunan Rencana Kerja Pemerintahan Daerah;

c) Rekomendasi bagi Perguruan Tinggi: melakukan exercise terkait kebijakan ecological fiskal transfer.

\section{Daftar Pustaka}

Bahl, Roy W. (1999). Fiscal decentralization as developmental policy. Journal of Public Budgeting \& Finance. Vol. 19 Issue 2 June.

Bahl, Roy W. and J. Linn. (1994). Fiscal decentralization and intergovernmental transfers in less developed countries. The Journal of Federalism. Vol 24 Winter.

Bahl, Roy W. and J. Linn. (1992). Urban Public Finance in Developing Countries. New York: Oxford University Press.
Bahl, Roy W. and S. Nath. (1986). Public expenditure decentralization in developing countries. Journal of Environment and Planning C: Government and Policy. Vol. 4 Issue 4 February.

Oates, Wallace. (1999). An Essay on Fiscal Federalism. Journal of Economic Literature. Vol. 37, No. 3 September.

Oates, Wallace. (1985). Searching for Leviathan: An Empirical Study. The American Economic Review. Vol. 75, No. 4 September.

Prud'homme, Remy. (1990). Decentralization of Expenditure or Taxes: The Case of France, Decentralization, Local Governments, and markets ed Bennett. Oxford: Claredon Press

Shadbegian, Ronald J. (1999). Fiscal federalism, collusion, and government size: Evidence from the States. Public Finance Review. Vol. 27 Issue 3.

Sidik, Machfud. (2004). Prinsip dan Pelaksanaan Desentralisasi Fiskal di Berbagai Negara. Bunga Rampai Desentralisasi Fiskal, Ditjen PKPD Jakarta.

Soepodo, Harsojo. (2003). Partisipasi Masyarakat Dalam Perencanaa, Pelaksanaan dan Evaluasi Pelayanan Publik di Kota Surakarta. Jurnal Forum Inovasi. Vol. 8 Edisi September.

Diamar, Son. (2003). Beberapa Catatan Kunci Dimensi Politik Pelayanan Publik. Jurnal Forum Inovasi. Vol. 8 Edisi September.

Kalla, Jusuf. (2003). Langkah Nyata Memperbaiki Mutu Pelayanan Publik. Jurnal Forum Inovasi. Vol. 8 Edisi September. Undang-Undang Nomor 22 Tahun 1999 tentang Pemerintahan Daerah. Undang-Undang Nomor 25 Tahun 1999 tentang Perimbangan Keuangan Pemerintah Pusat dan Pemerintah Daerah. Undang-Undang Nomor 32 Tahun 2004 tentang Pemerintahan Daerah. Undang-Undang Nomor 33 Tahun 2004 tentang Perimbangan Keuangan Pemerintah Pusat dan Pemerintahan Daerah. 